\title{
Mustafa Kemal Atatürk'ün Düşün Dünyasının Oluşumundaki Etkenlerle İlgili Bazı Görüşler
}

\author{
Haldun EROĞLU*
}

\section{ÖZET}

Mustafa Kemal Atatürk, öğrencilik yıllarından itibaren Osmanlı Imparatorluğunun artık yıkılmak üzere olduğunu yerine imparatorluğun asli unsuru olan Türklere dayalı bir milli devlet kurulması gerekliliğine inanıyordu. Yeni devletin hangi temeller üzerine kurulacağ $O^{\prime}$ nun düşünce dünyasının oluşumunda etken olan düşüncede gizli idi. Bu düşünce dünyasının oluşumunda etkili olan gerçeklerin neler olduğu ve düşün dünyasının nasıl oluştuğunun anlaşılması için okuduğu kitaplar ve etkilendiği düşün adamlarının kimler olduğuna bakmak gerekmektedir.

Anahtar Kelimeler: Mustafa Kemal Atatürk, Milliyetçilik, Babanzâde İsmail Hakkı, J J. Rousseau

\begin{abstract}
Mustafa Kemal Atatürk by his school years, claimed that it should be established the national state based on Turkic element of the empire which is on the verge of collapse. The foundations of new state which is necessary to found, are hired in the thought which is effective in the formation of His Thought. For undestanding the effective realities and how his thought shaped, It should be necessary to look for his reading books and men.
\end{abstract}

Key Words: Mustafa Kemal, Nationalism, Babanzâde İsmail Hakkı, J. J. Rousseau

Dr. Akdeniz Üniversitesi Fen-Edebiyat Fakültesi Tarih Bölümü. halduneroglu@yahoo.com 
Osmanlı İmparatorluğu'nun son üç yüz yıllık sürecinin son yüzyılı olan on dokuzuncu yüzyıl boyunca süren Türk çağdaşlaşma serüveninin' yol haritasında 1789 Fransız Devriminin yarattığı Ulusçuluk/Milliyetçilik akımının tutuğu yer bugün hemen hiç kimse tarafından inkar edilememektedir. Genel olarak dünya tarihinde on dokuzuncu yüzyıl, imparatorlukların yerlerini Ulus/Milli devletlere bıraktıkları yüzyıl olarak tarih sahnesinde yerini almıştır. Özellikle Osmanlı imparatorluğu açısından bakıldığında imparatorluğun on altıncı yüzyıl sonrasında bozulmaya başlayan yapısını düzeltmeye çalışmak amacıyla bir takım önlemler alınması düşünülmüş ve bu konuda bazı düşün adamlarının layiha, risale veya nasihat kitabı olarak görüşlerini dönemin hükümdar, şehzâde ya da devlet adamlarına sunmuşlardır. ${ }^{2}$ Ancak on altıncı yüzyıldan sonra imparatorluğun kötü gidişine dur demek için kurtuluş reçeteleri olarak kaleme alınan bu eserlerin genel karakteri bahsedilen bu kurtuluşun askeri tedbirlerle sağlanabileceği, ordu teşkilatının yeniden yapılandırılması gerektiği belirtilmektedir. Bu açıdan bakıldığında kitap sahipleri on altı ve on yedinci yüzyılda genel olarak devletin askerî düzeninin eskiden olduğu gibi disipline edilmesi gereğini savunurken on sekizinci yüzyıldan itibaren artık "Modern" Avrupa örnek alınması gereğinin altı çizilmiş ve askeri yapılanmanın Avrupalı tarzda bir ordu kurulması gerekliliğine dönüşmüştü. Türk çağdaşlaşma tarihi açısından asıl dönüşüm on dokuzuncu yüzyılda gerçekleşmiş ve kurtuluşun sadece askerî alanla sınırlı tutulmaması, hukuk, ekonomi ve günlük hayata ait yaşantılarında Avrupalılaşması konusunda fikirler ileri sürülmeye başlandı. Bir taraftan bu olurken diğer taraftan asıl olması gereken zihinsel dönüşümün gerçekleștirilmesi gerekliliğinin de savunan fikir adamları ortaya çıkmaktaydı. Özellikle imparatorluğun on altıncı yüzyıldan sonraki süreçte geri kalmışlığının sebebi olarak görülmesi gereken bahsedilen bu zihinsel dönüşümün gerçekleşmesi asıl kurtuluş reçetesi olduğu gerekliliği kendini göstermektedir.

Ortaçağ Avrupa tarihini ile kıyaslandığında, on üç-on beşinci yüzyıllar arasında aydınlık çağını yaşayan Osmanlı İmparatorluğu, Avrupa aydınlanmasının başlamasıyla birlikte geri kalmışlığın pençesine düşmüş bulunuyordu. Ortaçağ karanlığını yaşayan Avrupalı güçlere karşı Osmanlı üstünlüğünün kaynă̆ı olarak günün teknolojik üstünlüğüne sahip olmaları gerçeği göz ardı edilmemelidir. Modern askeri teknolojinin en üstün tekniklerini kullanan Osmanlı ordusu, Avrupalı askeri güçler karşısında üstün durumda bulunmaktaydı. Ancak on üçüncü yüzyıldan itibaren

' Türk Çağdaşlaşma Tarihi ile ilgili olarak bkz. Bernard Lewis, Modern Türkiye'nin Doğuşu, (çev Metin Kıratl1), TTK yay, Ankara 1996, Niyazi Berkes Türkiye'de Çağdaşlaşma, Doğu-Batı yay. İstanbul 1978.

${ }^{2}$ Bu konu ile ilgili olarak, Lütfî Paşa, Âsaf-nâme, (Neşr. 'Ali Emirî) İstanbul 1326, Koçi Bey Risalesi, (sad. Zuhuri Danışman), MEB yay. İstanbul 1997, Koca Sekbanbaşı Risalesi, (haz. Abdullah Uçman), Tercüman 1001 Temel Eser Serisi, Defterdar Sarı Mehmet Paşa Nesâythü'l-Vüzerâ ve'l-ümerâ veya Kitab-ı Güldeste, (Devlet Adamlarına Ögütler adı ile sad. Hüseyin Ragıp Uğural), Kültür Bak. yay. Ankara 2000. 
başlayan Avrupa aydınlanması ile birlikte bu dengenin değiştiğine şahit olunmaktadır. Avrupa devletlerinin yönetiminde etkin durumda bulunan kilisenin bu etkinliğinin kırılması ve düşün dünyasında hür fikrin gelişmesi olarak ifade edilen Rönesans ile așırı tutucu ve gelișmeye kapalı durumda bulunan Hıristiyanlık dinindeki düzenlemeler yani Reform, Avrupa'nın aydınlanması sürecini, bu aydınlanma sonucunda hür düşünce, dolayısıyla teknolojiyi kullanma, hatta üretme halini almastyla birlikte dünya yeni bir şekil aldı ve özellikle on altıncı yüzyıldan itibaren Osmanlı karanlığa gömülürken, Avrupa aydınlanmasını gerçekleştirmeye devam etti. Avrupa aydınlanmasının devam edişi sonucunda on sekizinci yüzyılın sonunda ortaya çıkan 1798 Fransız Devrimi ${ }^{3}$ ve on dokuzuncu yüzyıl boyunca gelecek yüzyılların şekillenerek insanlığın yeni bir dünya anlayışı ve yaşantısının benimseneceği Sanayi Devrimi $i^{4}$ gerçekleşti. Fransız Devrimi ve Sanayi Devrimi aslında daha önce İbn Haldun tarafından ortaya atılan imparatorlukların tıpkı insanlar gibi doğup, büyüyüp sonunda ölecekleri nazariyesini ${ }^{5}$ doğrularcasına Osmanlı imparatorluğunun sonunu hazırlamaya başladı. Bu süreç bütün dünyada imparatorluk anlayışlarını alt üst etti ve doğal olarak bundan en çok etkilenen Osmanlı imparatorluğu oldu.. Fetihçi Imparatorluk karakterli Osmanlı imparatorluğu özellikle on altıncı yüzyıl sonrasında artık yeni yerler ele geçirme şansı bulamamış ve sonun başlangıcı dönemine girilmişti. Gerçekte I. Süleyman, Viyana önlerine kadar giderken aslında Osmanlı imparatorluğunun klasik fetihçi yapısına göre hareket ediyordu. Ancak Viyana'dan mağlup olarak geri dönerken ise dünyanın kabuk değiştirerek yeniden şekillenmekte olduğunu ve yeni dünya düzeninde fetihçi imparatorlukların yerinin olmadığını da tescil etmiş bulunuyordu.

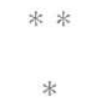

Osmanlı imparatorluğunun, özellikle on dokuzuncu yüzyıl, tarihi seyrinden haberdar olan Mustafa Kemal Atatürk, imparatorluğunun kurtuluşu için reçete hazırlayanlardan farklı olarak millî bir devlet kurularak Türk milletinin varolma savaşının kazanılmasını düşünüyordu. On dokuzuncu yüzyılın ikinci yarısından itibaren Osmanlı içerisinde güçlenen Türkçülük akımından etkilenenlerden birisi de Mustafa Kemal Atatürk idi. Yusuf Akçura tarafından üç devreye ayrılan Türkçülük faaliyetlerinin ilk

\footnotetext{
${ }^{3}$ Fransız Devrimi ile ilgili olarak bkz. Gurynne Lewis, "Fransız Devrimi (1789-99)", Batı'da Devrimler ve Devrimci Gelenek 1560-199I (der. David Parker-İng'den. Çev. Kemal Inal), Ankara 2003. s. 119-141, G. Lewis, The French Revolution, Rethinking the Debate, London 1993. T. Skocpol, Social Revulations in the Modern World, Cambridge 1994.

${ }^{4}$ Sanayi Devrimi ile ilgili olarak bkz. John Breuilly "1848 Devrimleri", Batl'da Devrimler ve Devrimci Gelenek 1560-1991 (der. David Parker-İng'den. Çev. Kemal İnal), Ankara 2003, s. 142-169, William H. Mcneill. Dünya Tarihi, (çev. Alaeddin Şenel), Ankara 1989. s. $372-375$.

${ }^{5}$ İbn Haldun Mukaddime, (çev.). MEB yay. İstanbul, s. $431 \mathrm{vd.}$
} 
evresi Kırım Savaşı sonrasına denk gelen ve Ahmet Vefik Efendi'nin öncülügüünde Şinasi Paşa, Mustafa Celaleddin Efendi ve Ziya Paşa'nın içerisinde bulunduğu 1865-1879 yıllarıdır. 1876'dan sonra ortaya çıkan ve 1880'li yılları ihtiva eden Süleyman Paşa, Özbekî Şeyhi Süleyman Efendi, Ahmet Mithat Efendi ve Ahmet Cevdet Paşa'nın öncülüğündeki Türkçülük hareketinin ikinci evresi yaşanmıştır. Üçüncü evre Türkçülüğü ise 18971900 yılları arasında Şemseddin Sami Bey, Necip Asım Bey, Bursalı Tahir $B e y$, gibi kişiliklerin öncülügüünde yürütülmüşsür. ${ }^{6}$

Yusuf Akçura, 1904 yılında Osmanlı imparatorluğunun hayatını nasıl devam ettireceği konusunda $\ddot{U}_{c ̧}$ Tarz-ı Siyaset adlı makaleyi kaleme alır ve Osmanlıcılık, Islamlılık ve Türklük siyasetlerini tartışır. Osmanlının kurtuluşunun bu üç siyasetten hangisi ile olabileceğini değerlendirir. Vardığı sonuca göre ise Osmanlıcılığın kesinlikle uygulanamayacağını artık Avrupa'da baş gösteren milliyetçilik akımlarının henüz yeni olmasına rağmen etkili olmaya başladığını belirtir. Diğer iki siyaset ile ilgili de aslında henüz hangisinin geçerli olabileceği konusunda kesin bir fikre sahip olmadı̆̆ını İslam ile ilgili "İslam, siyasî ve içtimaî işlere pek çok ehemmiyet veren dinlerden biridir. İslam' in esas kaidelerinden biri 'din ve millet birdir' düsturuyla ifade olunur. Íslam, mümin olan kimselerin cinsiyet ve milliyetlerini bitirir; lisanlarını kaldırmaya çalıșır mazilerini ananelerini unutturmak ister: 'İslam kuvvetli bir değirmendir ki farklı din ve cins müntesiplerini öğ̈̈tüp,dinen, cinsen bir, aynt haklara sahip, yekdiğerinden hiç farksız Müslümanlar çıkarır..." ${ }^{7}$ fikirler ileri sürer. Türk birliği siyasetinin de faydaları ve zararlarını sıralarken aslında Türk birliğinin doğuracağı zararların daha ziyade olduğunu kabul eder, fakat makalesini de "Hülasa, öteden beri zihnimi işgal edipte, kendi kendimi ikna edecek cevabı bulamadı̆̆ım sual yine önüme dikilmiş cevap bekliyor: Müslümanlık, Türklük siyasetlerinden hangisi Osmanlı devleti için daha yararlı ve kabil-i tatbiktir?" sorusuyla bitirir. ${ }^{8}$

Osmanlı İmparatorluğunun on dokuzuncu yüzyılın sonu ve yirminci yüzyılın hemen başındaki durumu, Mustafa Kemal Atatürk'ün büyüdüğü ve düşüncelerinin şekillendiği dönem olarak göze çarpmaktadır. Osmanlı imparatorluğu içerisinde gelişen akımlardan en önemlisi olan Türkçülük akımının Mustafa Kemal Atatürk'ü çok etkilediği ve bu devrin Türkçü akımlarını savunan düşün adamlarının kaleme aldıkları eserlerin Mustafa Kemal Atatürk tarafından çok dikkatle okunduğu da görülmektedir.

Mustafa Kemal Atatürk'ün siyasi fikirlerinin oluşumunun temelleri Harbiye öğrenciliği yıllarına dayanmaktadır. II. Abdülhamit'in Istibdat Dönemi'ne denk gelen bu süreçte Namık Kemal'in eserlerini okuyarak

\footnotetext{
${ }^{6}$ Yusuf Akçura, Yeni Türk Devletinin Öncüleri, (haz. Nejat Sefercioğlu) Kültür Bak. yay. Ankara 2001. s. 44-94.

${ }^{7}$ Yusuf Akçura, Ų̧ Tarz-l Siyaset, TTK yay. Ankara 1991, s. 31-32.

${ }^{8}$ Y. Akçura, a.g.e., s. 36.
} 
vatanperver ve özgürlükçü görüşlerin zihninde yerleştiğini Mustafa Kemal Atatürk kendi beyanatında belirtmektedir. "Harbiye senelerinde siyaset fikirleri baş gösterdi. Vaziyet hakkında henüz, nafiz nazar hâsıl edemiyorduk. Sultan Hamid devri idi. Namık Kemal Beyin kitaplarını okuyorduk. Takibat sıkı idi. Ekseriyetle ancak koğuşta yattıktan sonra okumak imkanın buluyorduk. Bu gibi vatanperverane eserleri okuyanlara karşı takibat yapılması, işlerin içinde bir berbatlı bulunduğunu ihsas ediyorduk. Fakat bunun mahiyeti gözlerimiz önünde tamamiyle tebellür etmiyordu." "Ali Fuat Cebesoy ve Asım Gündüz hatıralarında Mustafa Kemal Atatürk'ün Namık Kemal'i "Türk milletinin yüzyıllardan beri beklediği ses" olarak tanımladı ğını yazarlar. ${ }^{10}$

Mustafa Kemal Atatürk, 13 Ocak 1921 tarihinde Birinci Inönü Muharebesi ile ilgili Mecliste yaptığı konuşmada kendisini daha rüştiye öğrencisi iken kitaplarını okuduğu Namık Kemal'in bir şiirini okumuştur:

"Vatanın bağrına düşman dayadı hançerini

Yok mu baht kara kurtaracak maderini"

bu şiiri okuduktan sonra Mustafa Kemal Atatürk şöyle devam eder. "Iște bu kürsüden bu Meclisi âlinin reisi sıfatiyle heyet-i aliyenizi teşkil eden bütün âzanın her biri namına ve bütün millet namına diyorum ki:

Vatanın bağrına düşman dayasın hançerini

Bulunur kurtaracak bahtı kara maderini" "I

Mustafa Kemal Atatürk'ün Osmanlı imparatorluk fikrinin artık sona ermesi gerektiği ve bunun yerine Türk milletine dayalı bir millî devlet kurulması gerekliliğinin ortaya çıkması yönündeki düşüncesinin oluşumunda düşün adamları ve eserlerinin yanı sıra yaşadığı olaylarında etkisi büyüktür. Nitekim düşünce hayatında bunu pekiştiren iki olayın varlığı bilinmektedir. Bunlardan ilki Şam'daki garnizonda kavga eden iki erin arasına giren subayın Arap kökenli erin Kavm-i Necip olması dolayısıyla Türk erini azarlamasıdır. İkincisi ise, 1910 yilında Picardie Manevrasına giderken arkadaşı Binbaşı Selahaddin Bey'in başındaki fes yüzünden Sırp istasyonunda simit satan bir genç tarafından aşağılanmasıdır. ${ }^{12} \mathrm{Bu}$ iki olay daha yirminci yüzyılın hemen başında bir Osmanlı askeri olmasına rağmen, Mustafa Kemal Atatürk'ün düşüncesinde artık Osmanlılık fikrinin geçerliliğini yitirdiği, Fransız etkisiyle birlikte kendini gösteren milliyetçilik fikirlerinden hareketle imparatorluktan millî devlete geçiş yapılması gereğinin şekillenmesinde önemli etkiler yapmıştır. Daha öğrencilik

\footnotetext{
${ }^{9}$ Atatürk'ün Söylev ve Demeçleri, Atatürk Araştırma Merkezi yay. c. I., Ankara 1997, s. 205.

${ }^{10}$ Şerafettin Turan, Atatürk'ün Düşünce Yapısını Etkileyen Olaylar Dï̌sünürler Kitaplar, TTK yay. Ankara 1989, s. 7.

"Söylev ve Demeçler, c. I, s. 154.

${ }^{12}$ Ş. Turan, a.g.e., s. 4.
} 
yıllarından itibaren okuduğu kitaplar ve etkilendiği düşünürlerden kaynaklanan düşün dünyası bu iki olayla birlikte yepyeni bir çehreye bürünmüş ve Türk devletinin temelleri daha o devirlerde kafasında atılmıştır. Osmanlı imparatorluğunun sonunun geldiğine dair söylediği șu sözleri dikkat çekicidir. "Halep'te bulunduğum günler zarfinda memleketin vaziyet-i umumiyesini kendi kendime mülahaza ettim. Vaziyet şu idi. Müttefiklerimiz ve biz partiyi kaybetmiştik. Fakat Türkiye için mesele bütün mevcudiyetini kaybetmek neticesine varacak kadar mühlikti. O tarihte düşünülecek şey, kaybolduğuna şüphe kalmayan partiyi iade etmek olamazdı. Yalnız mevcudiyetimizi muhafaza için en seri ve kati çarelere başvurmakta tereddüt etmemeliydik. Hatta bu uğurda müttefiklerimizden ayr olarak icap ederse yeniden vaz'iyett almak zaruri olabilirdi."13

Bununla birlikte Mustafa Kemal Atatürk'ün batı dünyası ile ilgili fikirlerinin asıl şekillendiği ve batı dünyasının yaşantısını ve dünya görüşlerini algılamasını en çok etkileyen olay 1910 yılında Fethi Bey (Okyar), ve Binbaşı Selahaddin Bey ile birlikte katıldığı Fransa'daki Picardie Manevrası sırasındaki Paris gezintisi ve manevra sonrasındaki Fethi Bey ile birlikte Avrupa'da yaptıkları İsviçre, Hollanda ve Belçika'yı kapsayan on dört günlük seyahattir. ${ }^{14}$ Mustafa Kemal Atatürk'ün İsviçre, Hollanda ve Belçika seyahatleri sırasında ve aynı zamanda Sırp çocuk ile Selahaddin Bey arasında geçen diyalogun zihninde bıraktığı izlerin tazeliğini korurken, Avrupa hayatı ve özgürlük ortamı ile ilgili bizatihi görerek elde ettiği bilgiler zaten kitaplardan okuduğu ve düşün dünyasında yer eden sosyal hayat, düşünce ve yönetim biçimi ile ilgili görüşlerine yeni bir bakış açısı getirirken var olan düşüncelerini perçinlemiştir. Bu durum daha sonra yeni Türkiye Cumhuriyeti Devleti'nin kurulmasının akabinde Atatürk devrimlerinin temelini oluşturan düşünce dünyasının oluşumunun ilk safhalarıdır.

Mustafa Kemal Atatürk'ün Türk demokrasisinin Fransız Devriminden etkilendiğini fakat daha sonraları kendine has bir biçim aldığını ifade ederek milletlerin ihtilallerini yaparken kendi şartlarını göz önüne alarak gerçekleştirdiklerinin altını çizer ve Türk inkılabının da çıkış noktasının kendi ihtiyaçları olduğunu vurgular ve 8 Mart 1928 tarihinde Le Matin gazetesi muhabirine verdiği demeçte şunları söyler: "Fransız ihtilali bütün cihana hürriyet fikrini nefheylemişti ve bu fikrin halen esas ve menbal bulunmaktadır. Fakat o tarihten beri beşeriyet terakki etmiştir. Türk demokrasisi Fransız ihtilalinin açtığı yolu takip etmiş, lakin kendisine has vasf-ı mümeyyizle inkişaf etmiştir. Zira her millet inkılabını içtimai muhitinin tazyikat ve ihtiyacuna tabi olan hal ve vaziyetine ve bu ihtilal ve inkulabın zaman-ı vukuuna göre yapar."15

\footnotetext{
${ }^{13}$ Arı İnan, Düşünceleriyle Atatürk, TTK yay. Ankara 1983, s. 53.

${ }^{14}$ Mehmet Önder, Atatürk Bildirileri. Kültür Bakanlığı yay. Ankara 2002, s. 187-188.

${ }^{15}$ Söylev ve Demeçler, c. III, s. 120.
} 
Mustafa Kemal Atatürk'ün düşün dünyasının oluşumunda şüphesiz ki okuduğu kitapların büyük etkisi vardı. Mustafa Kemal Atatürk'ün düşünce dünyasının oluşumu ile ilgili olarak okuduğu kitaplardan bazıları şunlardır. İdare-i Harb ve Siyaset (Erich Ludendorf/terc. Süukrü Ali), Cemiyet-i Akvam, Imtizac-ı Akvam ve Vefa-i Ahd (Namık Kemal), Hammurabi Kanunları (Avram Galanti), Avrupa Milletleri Ruhiyatı (Alfred Feuillet/tec. Mustafa Rahmi), Tarihte Güzel Kadınlar (Mehmet Eniz), Mukavele-i Íçtimaiye/Toplum Sözleşmesi (Jean Jacques Rousseau), İlm-i İktisad Dersleri (Şarl Zaydek), Burjuva Demokrasisiyle Proleterya Diktatörlüğ̈i Üzerine Tezler (N. Lenin), İctimaiyat (Ali Kâmi), Sendikacılık, Dün ve Yarın (Güstav Le Bon), Fransa'da İktisadi Gelişmeler, Sosyalizm ve Kapitalizm Konusu, Hukuk-t Esasiye (Babanzâde İsmail Hakk1), Akl-l Selim (J Meslier/terc. Abdullah Cevdet), Hïrriyet (John Stuard Mill/terc. Hüseyin Cahit), Fenn-i Ruh (Büchner Ludwig/terc. Abdullah Cevdet), Ruhü'l-Kavanin (Montesque/ terc. Hüseyin Nazım), Dünya Tarihinin Müstakbel Safhası, Hindistan'ın Uygarlıkları (Güstav Le Bon), Arap Medeniyeti (Güstav Le Bon), Doğu Sorunu (Eduard Driault), Liberalizm (Emile Faguet), Ekonomi Doktrinleri (Charles Gide-Charles Rist), Avrupa Politikası (Emilıo Cestaler), Kabilelerden İmparatorluklara İlkel Toplum'da ve Eski Doğu'da Sosyal Örgüitlenme (A. Moret), Politika (Charles Benoist), Yurttaşlık Haklarının Talebi (R. Poincare), Milliyetçilik ve Uluslar Arasıcılık (Ramsey Muir), Yasal Bozulmuşluk ve Uluslar Arası Kölelik (Victor Castin), Modern Ingiltere ve Gelişimi (Louis Cazamian), Asya'nın Uyanışı İngiliz. Sömürgeciliği ve Halkların Issyanı (Rene Grousset), Kadın ve Tanrı (Giorgio Quartara), Fransa'nın Hükümeti (Joseph Bartelemy), İslam ve Müttefiklerinin Politikası (Enrico Insabato), Devrimler İle İlgili Yazılar (Maxime Gorki)

Mustafa Kemal Atatürk'ün düşün dünyasının oluşumunda önemli etkiler yapanlardan Fransız düşün adamları ve fikirleri de göz ardı edilmemelidir. Fransız düşünürlerin kaleme aldıkları eserlerini titizlikle okuduğu bilinen Mustafa Kemal Atatürk'ü yeni dünyada şekillenen yönetim biçimlerinden olan ve O'nu en çok etkileyen olgu, yeni bir rejim olan Cumhuriyet fikridir. Yeni kuracağı Türkiye Cumhuriyeti’nin yönetim şeklinin Cumhuriyet olacağını daha milli mücadeleden önce benimsemiş olduğu okuduğu kitaplarda Cumhuriyet ile ilgili kısımların çok dikkatle okumasından ve işaretlemesinden anlaşılmaktadır. Mustafa Kemal Atatürk, Cumhuriyet ile ilgili fikirlerini 1 Aralık 1921 tarihli konuşmasında şu şekilde dile getirmektedir. "Efendiler Millet bizi buraya gönderdi. Fakat ilâahirilömür biz burada milletin idaresini ve hakimiyetini mal-l mevrus gibi temsil etmek için toplanmıs değiliz. Ve sizi toplamak ve dağıtmak hakkına hiç kimse hazi değildir. Millet bilmelidir ki bir gün vekillerini toplar ve gönderir. Burayl hiç kimsenin tekyid etmeğe ve dağıtmaya hak ve salâhiyeti yoktur ve olmamalıdir."16

\footnotetext{
${ }^{16}$ Söllev ve Demeçleri, c. I., s. 205
} 
Mustafa Kemal Atatürk'ün kurduğu yeni Türk Devleti'nin yönetim biçimi olarak Cumhuriyet rejimini seçmiş olmasını ve O'nun düşün dünyasında bu fikri benimsemesinde Fransız düşün adamı Jean Jacques Rousseau'nun Mukavele-i İçtimaiye (Toplum Sözleșmesi) adlı eserinin önemli yer tuttuğu yönünde görüșler ileri sürülmektedir. ${ }^{17}$ Mustafa Kemal Atatürk, Fransız düşünür ve eseri hakkındaki fikirlerini 1 Aralık 1921 tarihli Meclis kürsüsünden yaptığı konuşmada şu şekilde ifade etmektedir. "Efendiler! Bu nazariyat-ı meşrutiyeti bulan en büyük filozofların bu nazariyatı kurmak için çalıştıkları eserleri tetebbu ettim. Bunlara nüfuz ettim. Benim gördüğüm şudur: düşünmüșler ve nasıl yapalım da bu kuvve-i müstebide o irade-i içtimaiye ve milliyenin dununda kalabilsin. Yahut sıfira müncer olabilsin diyorlar. Ve buna muvaffak olamamak yüzünden büyük ve derin bir tstırap duyuyorlar. Jean Jacques Rousseau'yu baştan nihayete kadar okuyunuz. Ben bunu okuduğum vakit, hakikat olduğuna kail olduğum, bu kitap sahibinde iki esas gördüm. Birisi bu ıstırap, diğeri bir cinnettir. Merak ettim. Ahvali hususiyetini tetkik ettim anladım ki: hakikaten bu adam mecnun idi. Ve hali cinnette bu eserini yazmıştır. Binaenaleyh: çok ve çok istinat ettiğimiz bu nazariye böyle bir dimağın ürünüdür."

Mustafa Kemal Atatürk'ün “istinat ettiğimiz nazariye” olarak adlandırdığı egemenliğin halka ait olduğu görüşü Rousseau'nun Mukavele-i İçtimaiye adlı ederinde Mustafa Kemal Atatürk tarafından altı çizilmiş olan şu satırlarla anlatılmaktadır. "Egemenlik hiçbir şekilde bırakılamaz ve devredilemez yine o nedene bağlı olarak vekaleten yürütülemez. Egemenlik kamuoyunun iradesini içerir. "19

Diğer taraftan bu görüşle ilgili olarak Mustafa Kemal Atatürk’ün egemenliğin halkta olmasını yanında devamı niteliğindeki yönetim şekli olarak da Cumhuriyet fikri konusunda da Rousseau'daki fikirlerini işaretlemektedir. Rousseau'nun kitabından Cumhuriyet ile ilgili altını çizdiği satırlar şunlardır. "halkın tümü yine halkın tümü hakkında karar aldığ zaman halk yalnızca kendisini dikkate alır ve ortaya çıkan ilişki asla bölünüp ayrılmaksızın belli bir bakış açısına göre olan bütün ile diğer bir bakış açısına göre olan bütün arasında ilişkilidir. $O$ zaman gerek karara bağlanan konu, gerekse karart olan irade genel olur ki bu benim yasa dediğim eylemdir Bu durumda yönetim biçimi ne olursa olsun yasa ile yönetilen her topluma Cumhuriyet derim. Her geçerli yönetim Cumhuriyetçidir." ${ }^{20}$

Ancak burada Rousseau'nun bu görüşlerine daha özürlükçü bir bakış açısıyla ele alarak eleştiren ve Mustafa Kemal Atatürk tarafından okunup önemli görülen yerlerin altının çizildiği ve aslında Mustafa Kemal

\footnotetext{
${ }^{17}$ Ş. Turan, a.g.e., s.13.

${ }^{18}$ Söylev ve Demeçler, c. I, s. 231.

${ }^{19}$ Atatürk'ün Okuduğu Kitaplar, (ter. Bekir Koç- Haldun Eroğlu), c. VII, Anıtkabir Yay. Ankara 2001, s.. 314.

${ }^{20}$ Atatürk'ün Okuduğu Kitaplar, c. VII, s. 288.
} 
Atatürk'ün Cumhuriyet fikrinin oluşmasında Fransız düşünür kadar Atatürk'ü etkileyen kişi olması kuvvetle muhtemel Babanzâde İsmail Hakkı'dır. O'nun H. 1329 (1911) baskı tarihli, Hukuk-ı Esasiye aldı eser Mustafa Kemal Atatürk tarafından dikkatle okunmuş ve cumhuriyet, hükümet, ulusal egemenlikle ilgili kısımların altı çizilmiştir. Babanzâde İsmail Hakkı, J. J. Rousseau'yu eleştirel bir gözle değerlendirirken, ayrıldı̆̆ı nokta hükümetin ancak halk tarafından seçilmesi gereğidir. Zira Rouessau'ya göre cumhuriyet hükümdarı ve hanedan hükümdarı farklılık göstermemektedir. Mustafa Kemal Atatürk'ün Babanzâde'nin kitabından altını çizdiği bu konudaki satırlar şu şekildedir. "Rousseau'nun gözünde her ne kadar geçerli olan hükümet şekli Cumhuriyet gerek ise de kendisi için Cumhuriyet hükümdarı ve hanedan hükümdarı ile kabul edilemez bir ayrlık olarak görmez. Gerçekte hükümetin tek temeli halk tarafindan seçilmesidir. Yönetimi gösteren hükümet kendilerini seçenlere her zaman bağlı olduktan sonra her ne şekle girerse girsin uygundur ",21

Bu durum göz önüne alındığında Mustafa Kemal Atatürk'ün Cumhuriyet fikrinin ve yönetim biçiminin şekillenmesinde Babanzâde İsmail Hakkı'nın ortaya koyduğu halk Cumhuriyeti fikri Rousseau'nun Cumhuriyet fikrinden farklılık göstermektedir. Bu farklılıklar dikkate alındığında Mustafa Kemal Atatürk tarafından benimsenen halka dayalı Cumhuriyet prensibinin Babanzâde İsmail Hakkı tarafından ileri sürülen görüşle örtüştüğü ve Mustafa Kemal Atatürk'ün de Babanzâde İsmail Hakkı'nın bu yöndeki fikirlerini yazdığı kitabını da çok dikkatle okuyarak bu konuların geçtiği satırları işaretlediği görülmektedir. Mustafa Kemal Atatürk, halk cumhuriyeti ile ilgili şunları söyler "Yeni kanunlar yapıldıkça, bilhassa Teşkilat-l Esasiye kañunu yapilırken saltanat taraftarları, padişah ve halifenin hukuk ve selahiyetinin tasrihinde ssrar ederlerdi. Biz bunun zamanı gelmediğini veya lüzum olmadığını beyan ederek o ciheti meskût bırakmakta fayda görüyorduk. İdare-i devleti, Cumhuriyetten bahsetmeksizin, hakimiyet-i milliye esasatı dairesinde, her an Cumhuriyete doğru yürüyen şekilde temerküz ettirmeye çalışıyorduk ${ }^{, 22}$

Nitekim Babanzâde İsmail Hakkı'nın belirttiği ve Mustafa Kemal Atatürk'ün her zaman önemle üzerinde durduğu gibi millî egemenliğin sembolü parlamentodur ${ }^{23}$ fikri oldukça dikkat çekicidir. Bu söylemle hemen hemen aynı olan şu cümleler de Mustafa Kemal Atatürk tarafından söylenmiştir. "Meclis yalnız milletindir. Ve ancak milletin vekillerinden mürekkebdir. Milletin verdiği selahiyet ve vezaifi ifa eden zevattan ibarettir. Binaenaleyh yalnız ve yalnız milletindir." ${ }^{24}$ Millî egemenlik, Mustafa Kemal Atatürk'ün üzerinde durduğu en önemli devrimdir. Nitekim "Yeni Türkiye

\footnotetext{
${ }^{21}$ Atatürk'ün Okuduğu Kitaplar, c. VIII, s. 230.

${ }^{22}$ Arı İnan, a.g.e., s. 71.

${ }^{23}$ Atatürk'ün Okuduğu Kitaplar, c. VIIl, s. 293.

${ }^{24}$ Kemal Aytaç, Gazi Mustafa Kemal Atatürk Din Politikası Üzerine Konuşmalar, Ankara Üniversitesi Türk İnkılap Tarihi Enstitüsü yay. Ankara 1986, s. 90.
} 
Devletinin ruh-i bünyanı Hâkimiyet-i Milliyedir. Milletin bilâ kayd ü șart hakimiyetidir" $^{25}$ cümlesi Büyük Millet Meclisinin duvarına Egemenlik Kayıtsız Şartsız Milletindir şeklinde yazılmıştır.

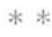

Mustafa Kemal Atatürk'ün kurtuluş savaşını başlatması ve devrimlerini gerçekleştirdiği süreçte özellikle üstünde durduğu milli bir ruh yaratmak olduğu bilinmektedir. Bu konu ile ilgili olarak da Alfred Feuillet'in Avrupa Milletleri Ruhiyatı adlı eseri dikkate değerdir. Bu eserin Mustafa Kemal Atatürk tarafından hemen her sayfası dikkatle okunmuş ve bazı yerlerin altı çizilmiş bazı yerlerin ise çarpı işareti konmuş olduğu görülür. Mustafa Kemal Atatürk, eserde İtalya'dan bahsedilen yerlerde yazar tarafından ileri sürülen "Siyasi birlik meydana getirilmiș olmasına rağmen çeșitli eyaletler arasındaki hoşgörüsüzlük, tamamen sönmüş değildir. Verilen terbiye eyaletlere göre başka başka olup henüz merkeziyet fikri yoktur. Bunun içindir ki Ocetti, İtalya'da Edebiyat adlı ölümsüz eserinde buna 'Milli ruh eksikliği' der. Milli ruh, milletin bir ideale sahip olmasıla doğar." paragrafında 'merkeziyet fikri' ve 'milli ruh eksikliğ i' kavramlarının altını kalın çizgilerle çizerek yanlarına çarpı işaretleri koymuştur. ${ }^{26}$ Yine aynı yazarın kaleminden çıkan şu satırlar da Mustafa Kemal Atatürk tarafından kalın çizgilerle işaretlenmiștir. "Hangi ırka mensup olursa olsun, milletler unutmamalıdır ki milli büyü̈klüğün yegane sartı yüksek bir ideale ve buna ulaşmak için sağlam bir ahlaka sahip olmaktır. Roma ve İtalya gibi olağanüstü şeyler meydana getiren bir halk da hayat hazinesi kuramaz. Fakat millet kuvvetini kullanmak konusunda hata yapmamalıdır. Her milletin en büyük ihtirası zeka, seciye ve ahlakça ilerlemek olmalıdır. .. milli birlik olmazsa görünürdeki birlik neye yarar. ${ }^{, 27}$ Mustafa Kemal Atatürk'ün düşünce hayatında bu bilincin çok önemli olduğunu bir kez daha belirtmek gerekir.

Aynı kitapta yer alan ve müziğin milli duygular üzerindeki etkilerinin anlatıldı̆̆ 1 cümlelerin altının çizildiği Mustafa Kemal Atatürk'ün Türk müziğine verdiği önemin aslında milli ruhun oluşturulmasındaki etkileri incelenmelidir. Eserde Mustafa Kemal Atatürk tarafından işaretlenen cümleler șöyledir: "Alman siyasî birliğine Alman millî duyguları da önemli hizmet etmiștir. Bu konuda Bismarc söyle der:'Okulda öğrenilen Alman şarkılarıdır ki Alman gönüllerini fethetmiştir. Ben bu türküleri Alman birliğini sağlayan en önemli etkenlerden sayarım"'² Mustafa Kemal Atatürk'ün bahsedilen bu millî birlik ve ruh ile ilgili olarak 25 Mart 1931

\footnotetext{
${ }^{25}$ Arn İnan, a.g.e., s. 63 .

${ }^{26}$ Atatürk'ün Okuduğu Kitaplar, c. V, s.. 320

${ }^{27}$ Atatürk'ün Okuduğu Kitaplar. c. V.s. 322.

${ }^{28}$ Atatürk' ïn Okuduğu Kitaplar, c. V, s. 350
} 
tarihinde Hakimiyet-i Milliye muharririne verdiği bir demeçte "Milletlerin tarihinde bazı devirler vardır ki, belirli maksada erebilmek için maddî manevî ne kadar kuvvet varsa hepsini bir araya toplamak ve aynı istikamete sevketmek gerekir. Yakın senelerde böyle bir toplanma ve birleşme hareketinin mühim neticelerini idrak etmiştir." ${ }^{29}$

Alfred Feuillet tarafından kaleme alınan ve Yunan, İtalyan, Fransız, Alman, İspanyol milletlerinin özelliklerini anlattığı Avrupa Milletleri Ruhiyatı adlı eseri çok dikkatle okuduktan sonra arkasına "bir gecede okudum. Çok enteresandı. Tekrar dikkatle okunacak notları vardır."notunu düşmesi bu esere ne kadar önem verdiğini göstermektedir. ${ }^{30}$

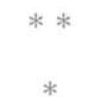

Mustafa Kemal Atatürk'ün kadınların sosyal hayattaki yerlerine önem verdiği çok iyi bilinmektedir. Nitekim bu fikrinin oluşumunda şüphesiz ki okuduğu kitaplardan etkilendiği göz ardı edilemez. Türk tarihinde kadının yerinin her zaman önde olduğu gerçeği Mustafa Kemal Atatürk'ün bu düşüncesine temel olmuştur. Rıza Nur'un Türk Tarihi adlı eserde Selçukluların acem etkisine henüz girmediği ilk dönemlerde kadının toplum içerisindeki yerinin önde olduğu daha sonraları Acem etkisi ile birlikte yok olduğunu söylediği fikirlerden etkilendiğini ileri sürmek yanlış olmasa gerektir. Nitekim Rıza Nur'un bu fikrinin geçtiği cümlenin altını çizmiştir. ${ }^{31}$ Mustafa Kemal Atatürk'ün okuduğu kitaplar sayesinde sahip olduğu düşünce hayatının şekillendiği ve modernlik konusunda tarihin derinlerinde kalmış gerçekleri ön plana çıkardığı görülmektedir. Avrupalı yazarlardan öğrendiği modern Avrupa hayatının özelliklerini yaptığı seyahatlerde netleştirdiği anlaşılmaktadır. Bunun yanı sıra özellikle Türk tarihi içerisinde Türk sosyal hayatının inceliklerine ve özelliklerine hakim olduğu, bu sayede yeni kurulan Türk devletinin sosyal hayatını yeni dünya hayatı ile aynı seviyeye getirmek için devrimlerini gerçekleştirdiği anlaşılmaktadır. Sosyal hayat ile ilgili en önemli devrimlerinden birisi de Türk kadınını sosyal hayatın içine çekmiş olmasıdır. Mustafa Kemal Atatürk'ün kadınları sosyal hayatta ön plana çıkarmak konusundaki fikirlerinin temelleri sadece modern Avrupa hayatında kadının aldığı yerle açıklamak yetersizdir. Nitekim Mustafa Kemal Atatürk'ün Türk kadınına verdiği önem Avrupa düşüncesinden daha önde idi. Bu bakımdan bu düşüncesinin oluşumu sadece Avrupa düşünce hayatından kaynaklanan bir durum değildi. Nitekim Selçukluların Acem etkisi altına girmeden önceki dönemlerde kadına toplum hayatı içinde verdiği rolün önemini bilen büyük önder bu konuda Türk tarihinde kadının toplum içerisinde aldığı yeri bilmekte ve bu bilgisi ile

\footnotetext{
${ }^{24}$ Söylev ve Demeçler, c. I., s. 236.

3) Ataturk' ü̈ Okuduğu Kitaplar, c. V, s. 354.

${ }^{31}$ Atatürk'ün Okuduğu Kitaplar, c. I, s..345.
} 
Türkiye Cumhuriyeti kadınına Türk kadının haklı olarak tarihte sahip olduğu itibarını geri vermiştir. Nitekim daha 1916 yılında hatıra defterine kadınlara serbestiyet verilmeli notunu düşmüştür. ${ }^{32}$

$$
\begin{gathered}
* * \\
*
\end{gathered}
$$

Mustafa Kemal Atatürk'ün kurduğu yeni Türkiye Cumhuriyeti'nin en önemli temel taşı laiklikdir. Ortaçağ Avrupası'nın en büyük sıkıntısı kiliselerin devlet politikalarında ön planda olması ve dinî anlayışın devlet yönetiminde etkili olmasıdır. Bu süreci yaşayan Avrupa'nın bu dönem Karanlık Çăg olarak adlandırılmış ve devletin din işlerinin etkisinden kurtarılmak istenmesi ile başlayan reform çalışmaları aynı zamanda Avrupa aydınlanmasının da başlangıcı olmuştur. Bu aydınlanma süreci modern dünyanın kurulmasının en önemli sebebidir. Bu süreç Avrupa'da ulusçulu ön plana çıkaran Fransız devrimini yaratmış ve yine bu aydınlanma süreci Sanayi devriminin ortaya çıkmasına sebep olmuştur. Avrupa'da bunlar yaşanırken on altıncı yüzyıldan itibaren milli kimliğini kaybederek çok uluslu, çok dilli ve çok dinli bir imparatorluk halini alan Osmanlı imparatorluğunda Avrupa'daki gelişmelerin tersine din anlayışının devlet üzerinde daha da etkin olmaya başladığı görülmektedir. Bu anlayışın geçerlilik kazanması ile birlikte imparatorluk son üç yüz yıllık döneminde yanlış politikalar ve uygulamalarla geri kalmışlık potasına girmiş bulunmaktaydı. Bu tarihi gerçeği gören Mustafa Kemal Atatürk, yeni kuracağı devletin en önemli devrimi olarak laiklik anlayışını devletin temel direği yapmıştır. Böylece din, gerçek kimliğine kavuşarak siyasallaşması önlenmişken devlet yönetimi üzerindeki etkisi azaltılmıştır. Osmanlı imparatorluğu tarafından dinin siyasete alet edilmesi Mustafa Kemal Atatürk tarafından dile getirilerek şöyle denmişti: "Bir taraftan dini siyasete alet ittihaz ederek Anadolu mücahitlerini idama mahkum ettiler. Ahaliyi mahut fetvalarla mukateleye teşvik eylediler. Bir taraftan da bazı pespayelerin ceplerini doldurarak Kuva-yi İnzibatiye veya Hilâfet Ordusu namıla üzerimize saldırdılar. Saf ve masum halkı bir çok tesniât ile iğfal ederek, dahilde yer yer isyan ateşini yaktırdılar." 33 diğer bir konuşmasında da asırlardan beri süregelen dinin siyasetten ayrılmasının hem dünyevî hem uhrevi bir zorunluluk olduğunu vurgulamaktadır. ${ }^{34}$

Mustafa Kemal Atatürk'ün özellikle İslam Tarihi üzerine okuduğu kitaplar onda bu fikirlerin güçlenmesine sebep olmuştur. Şerafettin Turan, Mustafa Kemal Atatürk'ün İslam tarihi konusunda özellikle Hüseyin Cahit tarafından Türkçe'ye çevrilen Leon Caetani'nin İslam Tarihi adlı eserinden çok etkilendiğini belirtir ve Mustafa Kemal Atatürk'ün Tarih II

\footnotetext{
${ }^{32}$ Arı İnan, a.g.e., s. 90.

${ }^{33}$ Arı İnan, Düşünceleriyle Atatürk, s. 55.

${ }^{34}$ Anı İnan, a.g.e., s. 87.
} 
Ortazamanlar kitabına İslam'ın peygamberinin hayatı ve savaşlarını yazarken İtalyan yazardan faydalandığını kaydeder. ${ }^{35}$ Ancak Mustafa Kemal Atatürk'ün İslam tarihi ile ilgili olarak Filibeli Ahmet Hilmi'nin Tarih-i İslam'1, M. Semseddin'in İslam Tarihi, Halil Edhem tarafından tercüme edilen Poole Stanley Lane'nin Düveli İslamiye adlı eseri, R. Dozy'nin İslam Tarihi Üzerine Denemeler adlı eserleri de okuduğu ve bunlardan da faydalandığ 1 kabul edilmelidir.

Mustafa Kemal Atatürk'ün İslam ve Halife ile ilgili düşüncelerinin oluşmasında yine okuduğu tarih kitaplarındaki bilgilerden faydalandığı bilinmektedir. Bu kitaplar arasında yer alan Deguignes'in Umumî Tarih adlı eserinde Gazneli Hükümdarı ile Bağdad Halifesi arasındaki savaş ve Sultan Mesut'un Halifeyi yendikten sonra kendisine karşı bir daha ordu toplamayacak, emirlerine uyacak olduğunu belirten satırların altını çizerek yanlarına da Osmanlıca Halife yazdığına şahit olunmaktadır. ${ }^{36}$ Aslında burada hem Türk hükümdarının siyasî açıdan İslam halifesine karşı üstünlüğünü hem de İslam halifesinin düştüğü durumun İslam dini ile ilgili olmadığı ve halifenin acziyeti ile birlikte bu makamın dinen ve siyaseten hiçbir manası olmadığını düşünmektedir. Nitekim 22 Ocak 1922 tarihli bir konuşmasında bu durumu açıkça belirterek hilafetin dinen ve siyaseten hiçbir mana ifade etmediğini belirtir. ${ }^{37}$ Aynı şekilde Filibeli Ahmet Hilmi'nin Tarih-i İslam adlı eserinde Abbasi halifeliğinin siyasi iktidardan yoksun bir çeşit şeyhlik derecesine inmiş olduğu yönündeki cümlesinin altı Mustafa Kemal Atatürk tarafından çizilmiştir. ${ }^{38}$

Osmanlı halifesinin her hangi bir etkisinin olmadığ 1 ve ortadan kaldırılması gerekliliği konusunda kesin tavır içinde bulunan Mustafa Kemal Atatürk, halifelik hayali kuranları hem İslam hem de Türkiye düşmanı olduğunu vurgularken, Osmanlı halifesini Sevres Anlaşmasına imza atmakla hainlik yaptığını belirterek ${ }^{39}$ bu konuda kimseye taviz verilmeyeceği ve Modern bir Türkiye kurulacağı yönündeki fikirlerini açıkça beyan etmektedir.

\section{SONUÇ}

Mustafa Kemal Atatürk, dünya tarihinde ender yetişmiş devlet, siyaset, asker ve de en önemlisi düşün adamlarından birisidir. Bu özelliklerinin oluşmasında onun yetiştiği ortam önemli bir yer tutmaktadır. Bahsedilen bu ortam Osmanlı imparatorluğunun yıkılıș süreceine denk gelen bir zaman dilimidir. Bu bakımdan Mustafa Kemal Atatürk, Osmanlı sonrasında nelerin olması yada nelerin yapılması gerektiği konusunda dönemin en önde gelen

\footnotetext{
${ }^{35}$ Ş. Turan, a.g.e., s. 33

${ }^{36}$ Atatürk'ün Okuduğu Kitaplar, c. I, s. 148-149.

${ }^{37}$ Arı İnan, a.g.e., s. 75.

${ }^{38}$ Atatürk'ün Okuduğu Kitaplar, s. 51.

${ }^{39}$ Arl İnan, a.g.e., s. 74-75.
} 
düşün adamlarının kitaplarını okuyarak dünyada olup biten her şeyden haberdar olarak hareket etmiştir. Mustafa Kemal Atatürk'ün düşün dünyasının oluşumunda yukarıda da kısa bir listesi verilen ve döneminin önde gelen bilim adamları tarafından kaleme alınan kitapların çok etkili olduğu çok açıktır. Ancak Mustafa Kemal Atatürk'ün düşün dünyasının oluşumunda etkili olan yazar ve görüşlerinden kendisi ve düşüncesine yakın olan tarafları aldığı ve karşı geldiği fikirlere de yine kitapların yanların düştüğü notlarla ya da ünlem işaretleri ile çekincelerini belirttiği görülür. Bu açıdan bütün bu kitapların tamamen etkisinde kalarak onlardan etkilendiğini ileri sürmek yeterli değildir. Mustafa Kemal Atatürk hem bu kitapları okuyarak bilgi sahibi olmuş hem de kendisi için doğru olmayan yerleri de eleştirel bir gözle değerlendirmiştir. Bu açıdan bakıldığında Mustafa Kemal Atatürk'ün yeni bir Türkiye cumhuriyeti ve modern bir Türk toplumu yaratma çabası tesadüfi gelişmeler sonucu değil, daha öğrencilik yıllarından itibaren başlayan düşünce dünyasının şekillenmesinde modern dünyayı meydana getiren düşüncenin etkisi büyüktür. Bu açıdan Mustafa Kemal Atatürk'ün düşün dünyasının şekillenmesinde Modern dünya anlayışının etkileri görülür. Filibeli Ahmet Hilmi'nin Tarih- $i$ İslam adlı eserinde yazar tarafından kaleme alınan şu cümlelerin altı Mustafa kemal Atatürk tarafından çizilmiștir. "Eğer, Avrupa zihniyeti ve teșkilatını bilen bilim adamları yetişebilirse, o zaman sorunun rengi değişir. Ancak böyle bilim adamlarının yetişmesi için en az yarım yüzyll gerekir... Avrupa medeniyetinine belirgin özelliği "gelişim hızı", 'girişimi hızı', 'uygulama hızı' olduğuna bakılırsa hiç olmazsa onlara yetişebilmek için hızlı ve pratik önlemler alınması lazımdır zaruridir. ${ }^{40}$ Mustafa Kemal Atatürk'ün, Türkiye cumhuriyetinin kurulması, gelişmesi ve toplumsal düzende devrimler yapılmasında gösterdiği hızlılık ve daha sonraki yıllarda Türk gençlerini Avrupa'da bilimsel çalışmalara devlet bursları ile göndermesinin altında yatan gerçeğin. Filibeli Ahmet Hilmi tarafından kaleme alınan bu cümlelerin içinde yattığını ve Mustafa Kemal Atatürk'ün düşün dünyasının oluşumunda devrin önde gelen düşün adamlarının ve kaleme aldıkları bilimsel eserlerin çok etkili olduğunu ileri sürmek yanlış olmasa gerektir. Bu açıdan Mustafa kemal Atatürk'ün düşün dünyasının nasıl şekillendiğini algılamak için dönemin dünyasını, düşün hayatını, ve okuduğu eserleri çok iyi değerlendirmek gereği kendini göstermektedir.

\footnotetext{
“' Atatürk'ün Okuduğu Kitaplar, s. 57.
} 